\title{
Kommunikáció az egészségügyben - jogi vonatkozások
}

\author{
Mina András dr. \\ Országos Betegjogi, Ellátottjogi, Gyermekjogi és Dokumentációs Központ, Budapest
}

\begin{abstract}
Az egészségügyi (azon belül is az orvos-beteg) kommunikáció jogi vonatkozásait tekinti át a cikk, különös tekintettel az orvos-beteg kapcsolat alakulására, a tájékoztatás felelősségére, a nem kívánt események közlésére, a szükséges nyilatkozatokra. Orv. Hetil., 2016, 157(17), 675-679.
\end{abstract}

Kulcsszavak: egészségügy, kommunikáció, orvos-beteg kapcsolat, tájékoztatás, felelősség

\section{Communication in health care - legal aspects}

This paper is focusing on the legal aspects of communication in health care, especially on doctor-patient relationship, responsibility for information, communication of adverse events, and legal declarations.

Keywords: health care, communication, doctor-patient relationship, information, responsibility

Mina, A. [Communication in health care - legal aspects]. Orv. Hetil., 2016, 157(17), 675-679.

(Beérkezett: 2016. február 26.; elfogadva: 2016. március 17.)

\section{A kommunikáció: gyógyít és öl}

Az emlékezet formájában tárolt tapasztalatok és a közösen megfogalmazott célok kommunikációja nélkül nincs eredményes, egészséges társadalom.

Mindig mindenki kommunikál. Ha még meg sem született magzat - akkor is. Ha szótlanul ül a sarokban a gyerek - akkor is. Ha esetleg a nagypapa gondolatainak már csak az emléke él, de az tovább él - akkor is.

A kommunikációnk lehet közömbös a másik felé, jobbá teheti a világunk egy részét, esetleg romba döntheti a másik ember életét. Az orvosi kommunikáció is lehet ilyen két-három élü fegyver: gyógyíthat is, de ölhet is. Ráadásul: az orvos gyógyító személyisége tudatosan képes (kellene legyen) saját káros kommunikációs hatásai észlelésére, megelőzésére.

$\mathrm{Az}$ orvosi kommunikációnak a felelőssége is kettős: köteles elősegítenie a páciens gyógykezelését/gyógyulását, de azt is elfogadjuk, hogy ennek érdekében joggal érdeklődik az orvos az életünk intim dolgai felól. Ezekhez az információcserékhez írott és íratlan társadalmi elvárások adnak keretet (udvariassági és kulturális szabályok, etikai megfontolások, házirendek, szakmai protokollok és jogszabályok).

\section{A kommunikáció kockázatai és előnyei}

Az orvos-beteg kommunikáció egyrészt tehát bizonyos elvárásoknak kell megfeleljen, vagyis szabálykövetést (értékrendkövetést) jelent. A szabályt követő orvos számos kellemetlenségtől kíméli meg magát:

- nem idézi be bántó hangnem miatt meghallgatásra a kamara etikai bizottsága,

- nem indul ellene fegyelmi jellegú eljárás a munkahelyén,

- nem fogják kártérítési perbe a munkahelyét.

Másrészt azonban a helyes egészségügyi kommunikáció „mögöttes” értelme is nyilvánvaló:

- pontosabb orvos-beteg adatcseréból pontosabb diagnózis születhet,

- a beteg együttmúködőbb és elégedettebb lehet (compliance),

- nagyobb lehet az egészségnyereség, sikeresebb a betegellátás.

Ha az orvosok a defenzív (jogi stb. hátrányokat kerülő) magatartáshoz képest egy kicsivel több időt fordítanának a kommunikációra, jelentősen több szakmai és kommunikációs nyereséget realizálhatnának, még a fentieken túl is. Javítható lenne a beteg: 
- érzelmi helyzete (türelmesebbé, nyugodtabbá válik az orvos gyógyítási környezete, még nem kívánt esemény bekövetkezése esetén is nagyobb lehetne így a permegelőzés esélye),

- tájékozottsága, önrendelkezési pozíciója (bátrabban, nagyobb bizalommal és az orvosát kérdezi, tájékozottabb részese a közös döntéseknek, pontosabban, eredményesebben hajtja végre a döntéseket).

\section{Az egészségügyi szereplők kommunikációjára vonatkozó elvárások}

Az orvos-beteg kommunikációval kapcsolatos legfontosabb írott szabályokat (és következményeiket) elsôsorban az ágazatot átfogó alapjogszabályból, az egészségügyi törvényből (Eütv.) [1] kiindulva érdemes áttekinteni. (Megfelelően értelmezve, kompetenciakörre vonatkoztatva az „orvosi” fordulatok alkalmazhatók más egészségügyi dolgozókra vagy egészségügyi szereplőkre is.) A kommunikációra vonatkozó paragrafusok (1. és 2. táblázat) (érthetően) jobbára a szakmai tartalmi elemek- re fókuszálnak, azonban a törvény szellemiségéból és a szakmai kamarák etikai kódexeiból a kommunikáció megvalósulási módjára, mikéntjére is lehet következtetni (hangnem, empátia, etika).

Az Eütv.-en kívül írott források lehetnek még például a kapcsolódó egyéb jogszabályok, intézményi belső utasítások, minőségügy, panaszkezelési szabályzat, munkaköri leírás, szakmai ajánlások stb. Ezek alapelvei az Eütv.ből (is) levezethetők.

A kommunikáció íratlan normáinak áttekintésétől a helyszúke és a nehéz jogi megragadhatóság miatt most eltekintünk (idetartozhat a testbeszéd, a protokoll, a divat, kulturális szokások, szocializáció, közvélekedés stb.).

Az 1. és 2. táblázat szakmai érdeklődőknek szól: nem más, mint kérdéses kommunikációs helyzetekre vonatkozó „jogi könyvjelzők” listája (esetleges jogi/etikai eljárásokban, lásd a táblázatok 4. oszlopa: „eljáró szervek”).

Egy-egy védendő jogi érték több területen is felvetődhet - átfedések esetén igyekeztem a tipikusabb élethelyzeti csoporthoz sorolni ezeket (lásd a táblázatok 1. oszlopa: „csoportjellemző””).

\section{Kommunikáció során (is) tiszteletben tartandó értékek (1. táblázat)}

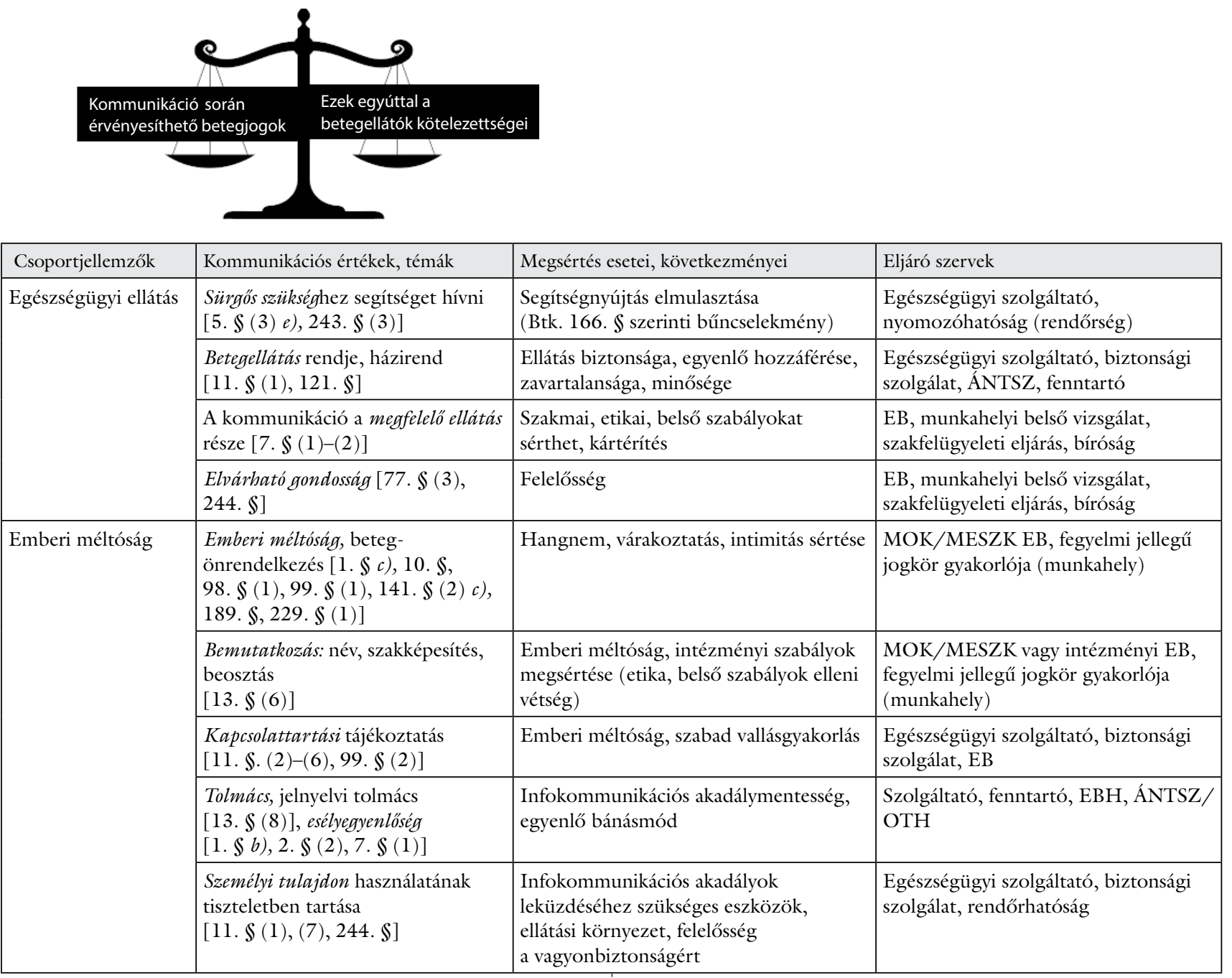


(1. táblázat folytatása)

\begin{tabular}{|c|c|c|c|}
\hline Csoportjellemzők & Kommunikációs értékek, témák & Megsértés esetei, következményei & Eljáró szervek \\
\hline & $\begin{array}{l}\text { Halottkezelés, kegyeleti tájékoztatás } \\
{[220-222 / \mathrm{A} \$]}\end{array}$ & Kegyeleti jogok & $\begin{array}{l}\text { Egészségügyi szolgáltató, EB, } \\
\text { ÁNTSZ, bíróság }\end{array}$ \\
\hline \multirow[t]{8}{*}{ Tájékoztatás } & $\begin{array}{l}\text { Személyre szabott, teljes körü } \\
\text { információadás a tájékozott } \\
\text { döntésekhez }[5 . \$(3) \text { a), 13-14. } \$ \text {, } \\
\text { 15. } \$(3), 16 . \$, 56 . \$(3), \\
134-136 . \$, 168 . \$, 171 . \$, \\
187 . \$, 191 . \$]\end{array}$ & $\begin{array}{l}\text { Beteg önrendelkezési, tájékozódási joga, } \\
\text { például rizikók, kimenetel, sikeresség } \\
\text { megismerése (szakmai irányelvek, } \\
\text { szabályok sértése, kártérítés) }\end{array}$ & $\begin{array}{l}\text { Egészségügyi szolgáltató, ÁNTSZ/ } \\
\text { OTH szakfelügyeleti eljárás, bíróság }\end{array}$ \\
\hline & $\begin{array}{l}\text { Egészségnevelés, prevenció, } \\
\text { gondozás, integráció, gyermek- } \\
\text { védelmi jelzőrendszer }[38 . \$(5), \\
42-43 . \$, 50 . \$, 80 . \$, 83 . \$]\end{array}$ & $\begin{array}{l}\text { Életvezetési ismeretek, rizikófelmérés, } \\
\text { tanácsadás, egészségkultúra }\end{array}$ & Egészségügyi szereplők \\
\hline & $\begin{array}{l}\text { Panasztételi, jogvédelmi, } \\
\text { jogorvoslati tájékoztatás } \\
{[29 . \$, 33 . \$, 34 . \$]}\end{array}$ & Betegjogok, jogorvoslat & $\begin{array}{l}\text { Egészségügyi szolgáltató, ÁNTSZ, } \\
\text { OBDK }\end{array}$ \\
\hline & $\begin{array}{l}\text { Egészségügyi erőforrások hatékony } \\
\text { felhasználása } \\
[1 . \$ f), 75 . \$(4)]\end{array}$ & Egyenlő hozzáférés & $\begin{array}{l}\text { Egészségügyi szolgáltató, OEP, } \\
\text { OGYÉI }\end{array}$ \\
\hline & $\begin{array}{l}\text { Téritési díjjal kapcsolatos } \\
\text { információk }[13 . \$(9), \\
142 . \$(6), 207 . \$, 226 . \$]\end{array}$ & Finanszírozási szabályok & $\begin{array}{l}\text { Egészségügyi szolgáltató, fenntartó, } \\
\text { OEP, NAV }\end{array}$ \\
\hline & $\begin{array}{l}\text { Munkaterápiás tájékoztatás } \\
{[195 . \$]}\end{array}$ & Önrendelkezés, bérügy, adóügy & $\begin{array}{l}\text { Egészségügyi szolgáltató, ÁNTSZ, } \\
\text { EB, NAV }\end{array}$ \\
\hline & $\begin{array}{l}\text { Külföldiek tájékoztatása } \\
{[13 . \$(8), 243 . \$]}\end{array}$ & Ellátás, finanszírozás & Egészségügyi szolgáltató, OEP \\
\hline & $\begin{array}{l}\text { Egészségügyi válsághelyzetben } \\
\text { kommunikáció [228-230.\$] }\end{array}$ & Ellátás, korlátozások, kártalanítás & $\begin{array}{l}\text { Egészségügyi szolgáltató, ÁNTSZ, } \\
\text { OTH, Védelmi Bizottság, EMMI }\end{array}$ \\
\hline \multirow[t]{6}{*}{ Önrendelkezés } & $\begin{array}{l}\text { Saját egészségügyi dokumentáció } \\
\text { adatainak megismerése } \\
{[14 . \$, 24 . \$, 30 . \$ \text {, }} \\
136-137 . \$, 193 . \$, 215 . \$]\end{array}$ & Adatok megismerése, adatvédelem & $\begin{array}{l}\text { Munkahelyi belső vizsgálat, OEP, } \\
\text { szakfelügyeleti eljárás, ÁNTSZ, } \\
\text { OBDK, NAIH, bíróság }\end{array}$ \\
\hline & $\begin{array}{l}\text { Egészségügyi ellátás beteg általi } \\
\text { visszantasitása }[20-23 . \$ \\
136 . \$, 219 . \$(3), 243 . \$(5)]\end{array}$ & $\begin{array}{l}\text { Élethez, testi épséghez való jog, vagy } \\
\text { emberi méltósághoz, önrendelkezéshez } \\
\text { való jog, kegyeleti jog }\end{array}$ & $\begin{array}{l}\text { Egészségügyi szolgáltató, EB, } \\
\text { munkahelyi belső vizsgálat, } \\
\text { szakfelügyeleti eljárás, bíróság, } \\
\text { rendőrhatóság }\end{array}$ \\
\hline & $\begin{array}{l}\text { Intézményelhagyás ideje, módja, } \\
\text { következményei }[12 . \$, 94 . \$(6), \\
\text { 189. \$, 192.\$, 197.\$(8)-(11), } \\
\text { 199. \$, 201/B \$] }\end{array}$ & $\begin{array}{l}\text { Szakmai, etikai, belső szabályokat, } \\
\text { betegbiztonságot sérthet, kártérítés }\end{array}$ & $\begin{array}{l}\text { EB, munkahelyi belső vizsgálat, } \\
\text { szakfelügyeleti eljárás, bíróság }\end{array}$ \\
\hline & $\begin{array}{l}\text { Transzplantációs információk } \\
\text { betegnek, hozzátartozóknak [19.\$ } \\
(2), 206 . \$, 209-211 . \$, 226-227 . \\
\$, 243 . \$(4),(11)]\end{array}$ & $\begin{array}{l}\text { Önrendelkezés, kegyeleti jogok, } \\
\text { kártalanítás }\end{array}$ & $\begin{array}{l}\text { EB, munkahelyi belső vizsgálat, } \\
\text { szakfelügyeleti eljárás, bíróság }\end{array}$ \\
\hline & $\begin{array}{l}\text { Reprodukciós tájékoztatás }[167- \\
\text { 168. } \$, 171 . \$, 176 . \$, 187 . \$(2)]\end{array}$ & $\begin{array}{l}\text { Önrendelkezési, reprodukciós } \\
\text { (meddőségkezelési, mûvi meddővé } \\
\text { tételi) jog, finanszírozás }\end{array}$ & $\begin{array}{l}\text { Egészségügyi szolgáltató, EB, } \\
\text { ETT-HRB, OEP }\end{array}$ \\
\hline & $\begin{array}{l}\text { Kutatásetika }[159 . \$, 164 / \mathrm{A} \$(1) \\
\text { 164/C } \$(1), 186 . \$]\end{array}$ & $\begin{array}{l}\text { Önrendelkezés, költségtérítés, } \\
\text { kártalanítás, kártérítés }\end{array}$ & $\begin{array}{l}\text { Monitoring szervezet, IKEB, } \\
\text { ETT-TUKEB, felelősségbiztosítók }\end{array}$ \\
\hline \multirow[t]{2}{*}{$\begin{array}{l}\text { Adatkezelés, } \\
\text { adatvédelem, } \\
\text { titoktartás }\end{array}$} & $\begin{array}{l}\text { Dokumentáció - az egészségügyi } \\
\text { ellátás része }[3 . \$ p), 10 . \$(5), \\
12 . \$, 20 . \$, 98 . \$(5), 101 / \mathrm{C} \$ \text {, } \\
136-137 . \$, 192 . \$(5), 194 . \$(2), \\
208 . \$, 210 / \mathrm{A} \$(2), 214 . \$]\end{array}$ & $\begin{array}{l}\text { Dokumentációs szabályok (adatkezelés, } \\
\text { adatvédelem, iratkezelés) }\end{array}$ & $\begin{array}{l}\text { Munkahelyi belső vizsgálat, ÁNTSZ/ } \\
\text { OTH szakfelügyeleti eljárás, NAIH, } \\
\text { bíróság }\end{array}$ \\
\hline & $\begin{array}{l}\text { Beteg ellátási adatairól tájékoztatás } \\
\text { másnak }[11 . \$(2), 25 . \$ 78 . \$(2), \\
127 . \$(2), 129 . \$(3), 134 . \$(2), \\
136 . \$, 138 . \$, 243 . \$(8)]\end{array}$ & Titoktartás, adatvédelem & $\begin{array}{l}\text { EB, munkahelyi belső vizsgálat, } \\
\text { szakfelügyeleti eljárás, NAIH, bíróság, } \\
\text { konzulátusok }\end{array}$ \\
\hline
\end{tabular}




\section{Kommunikáció során (is) számon kérhetô értékek (2. táblázat)}

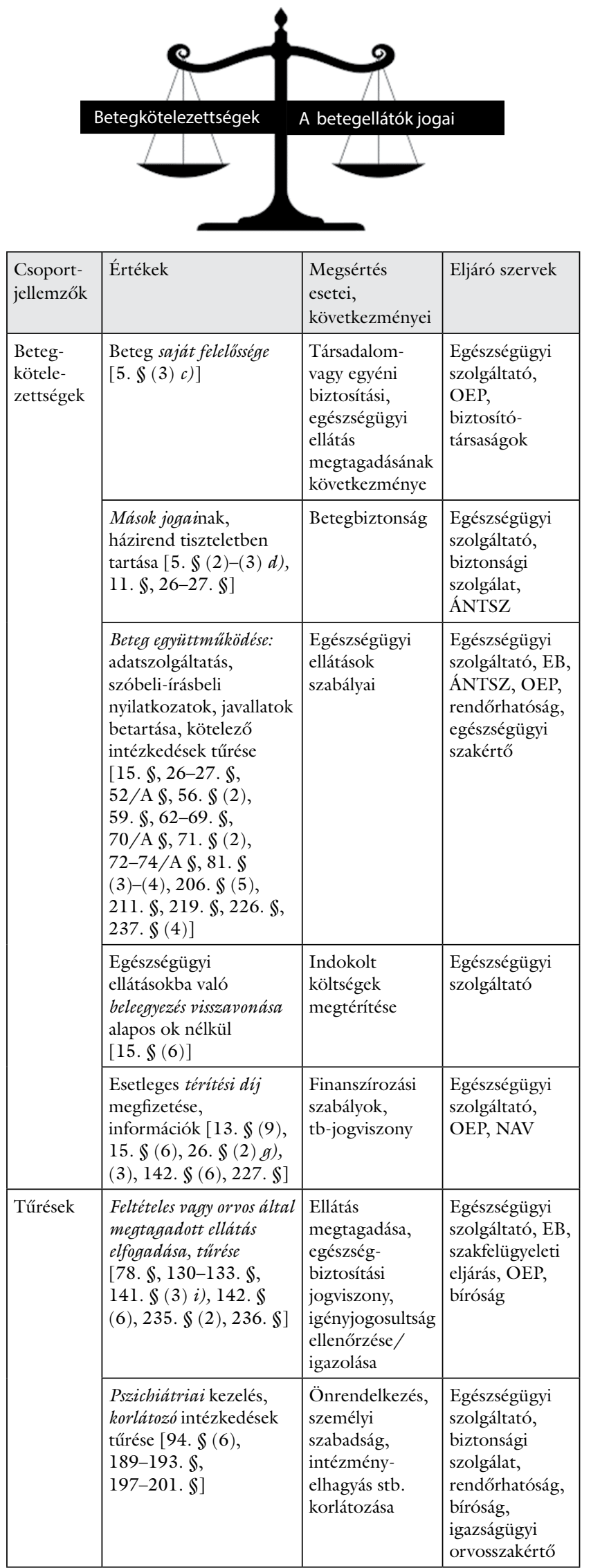

\section{Határidők}

A kommunikációval megsértett normák miatti etikai eljárást a Magyar Orvosi Kamara (MOK) [2] vagy a Magyar Egészségügyi Szakdolgozói Kamara (MESZK) [3] Etikai Bizottsága (EB) indítja a tudomásszerzéstől számított fél vagy a cselekménytől számított 3 éven belül. (Ha ugyanabban az ügyben szabálysértési vagy büntetőeljárás is indult, akkor a jogerős döntésrőll való értesüléstől számított 3 hónapon belül.) Jogvesztő határidőn túl is indítható etikai eljárás, ha azt az egészségügyi dolgozó saját maga ellen kéri.

A munkahelyi vezető (a munkáltatói jogkör gyakorlója) a munkavállalóra vonatkozóan annak vétkes kötelezettségszegésért (belső „fegyelmi” szabályzatban rögzített részletek alapján) 1 éven belül, írásban indokolt jogkövetkezményeket állapíthat meg (például figyelmeztetés, magatartásra kötelezés, maximum egyhavi alapbér mértékú pénzmegvonás). Kommunikációval okozott súlyos, gondatlan károkozásnál (például jelentős anyagi vagy egészségügyi hátrányt okozó tévedésnél, esetleg személyiségi jogsértésnél) 4 havi, szándékos vagy súlyosan gondatlan károkozásnál esetleg a teljes elégtétel (például sérelemdíj vagy kártérítés formájában kért) megtérítésére kötelezhető a dolgozó a munka törvénykönyve (Mt.) [4] alapján [2012. évi I. tv. 56. $\$(2), 179$ \$ (3)]. Kirívó esetben a munka-, jogviszony akár azonnal is megszüntethető (Mt. 78. \$). Hasonló szabályok vonatkoznak a közalkalmazottakra (Kjt. 33/A \$) [5], illetve az esetleg közszolgálati [6] jogviszonyban állókra is (Kttv. 64-64/A \$).

Az Állami Népegészségügyi és Tisztiorvosi Szolgálat/ Országos Tisztifőorvosi Hivatal (ÁNTSZ/OTH) szakfelügyeleti eljárás fél (maximum egy) éven belül kezdeményezhető [7].

Kártérítés, személyiségi jog megsértése miatt polgári peres eljárás 5 éven belül indítható polgári bíróságon [8].

Adatvédelmi jogsértés esetén a Nemzeti Adatvédelmi és Információszabadság Hatóság (NAIH) [9] előtti hatósági eljárásra is 5 év áll rendelkezésre.

Egyenlö Bánásmód Hatóság (EBH) [10] előtti hatósági eljárás 3 éven belül kérhető.

Büntetőbiróságon általában a büncselekmény büntethetőségének felső határáig (vagy elévülésig), minősítéstől függően 1-10 évig, de minimum 5 évig indítható per (például foglalkozás körében elkövetett veszélyeztetés, testi sértés, kutatási szabályok megsértése, tiltott szerv-, szövetfelhasználás, egészségügyi termék meghamisítása, kuruzslás vagy egészségügyi önrendelkezés megsértése miatt) [11].

Vélt vagy valós jogsértő szituáció tisztázásához, a lehetséges eljárások, jogorvoslatok kérdésében az intézményen belül tapasztaltabb munkatársakhoz, vezetőkhöz, intézményi jogászhoz lehet fordulni. Intézménytől független tanácsadás (például mediáció) az Országos Betegjogi, Ellátottjogi, Gyermekjogi és Dokumentációs Központ (OBDK) [12] területileg illetékes betegjogi képviselőjétől is kérhető. (Permegelőző eljárásra a fenti 
jogorvoslati lehetőségeken túl elméletileg az Egészségügyi Közvetítői Tanács [13] is felkérhető, de erre nem nagyon van példa, inkább választanak egyéb, alternatív vitarendezési módokat a felek.)

\section{Tipikus kommunikációs hibák}

Kommunikáció kapcsán a legnagyobb felelősség talán a beteg állapotáról, kezeléséről tájékoztatást nyújtót terheli (Eütv.). Gyakoriak a szolgáltatók betegtájékoztatási hiányosságai [14], de az ellátó és finanszírozási rendszer sem segíti, ösztönzi a kezelőorvost abban, hogy kimerítően magyarázzon egy információra éhes betegnek a betegségéről, a választási lehetőségeiről, a lehetséges szövődményekről. Megfelelő (finanszírozott) időráfordítás nélkül ez többnyire nem is megvalósítható.

A bírói ítélkezési gyakorlat pedig következetesen megítéli a „teljes körü” tájékoztatás elmaradása miatti kárigényeket [Eütv. 13. \$(1)] [15]. Még aláírt betegtájékoztatók és beteg-beleegyezó nyilatkozatok mellett is komoly nehézséget jelent a szolgáltatóknak bizonyítani, hogy az „egyéniesített”, szóbeli tájékoztatás során a beteg minden „további” kérdését is feltehette. Ehhez az kellene, hogy az orvos-beteg kommunikáció tényleges részleteit tükrözze az aláírt beteg-beleegyező nyilatkozat (lassan már hangfelvételben kellene gondolkodni). Emiatt (is) válnak az orvosok képernyőt (és nem beteget) tekintó, dokumentáló „gépekké”.

A várakozó betegek egyre emelkedő száma és a finanszírozási korlátok mindeközben szembemennek a fenti kívánalmakkal.

Tipikusnak és kritikusnak mondható még, hogy kinek, mikor, mi kommunikálható a betegról. Kevésbé köztudott, hogy kiskorút, korlátozottan cselekvőképest, pszichiátriai beteget is megilleti a helyzethez mért tájékoztatás. Ezzel párhuzamosan (és kontaktusképtelenség esetén is) a törvényes képviselőt, támogatót, nevezett vagy helyettes döntéshozót (valamint bizonyos esetekben a hozzátartozókat) is megfelelően tájékoztatni kell. Ez természetesen nem jelenti azt, hogy a kommunikáció az érdemi ellátás rovására mehetne: prioritást mindig a szakmai sürgösség és ellátási (munka)rend élvez. A tájékoztatás csak ez után (vagy ha van rá idő: e mellett) következhet. (A kommunikáció során nyerhető hasznos adat a gyógyítás eredményességét is befolyásolhatja!)

Lehetőség szerint hitelesen igazolt személyazonosságú, rokoni kapcsolatú hozzátartozó kapjon információt, kétség esetén az információ visszatartható, vagy a személy (például az élettársi kapcsolatra, szülői felügyeleti jogra nézve) írásban megnyilatkoztatható. Telefonban a beteg neve alapján az ottléte megerősíthető, egyéb adat (diagnózis, állapot stb.) nem közölhető.

Anyagi támogatás: A közlemény megírása, illetve a kapcsolódó kutatómunka anyagi támogatásban nem részesült.
A szerző a közlemény végleges változatát elolvasta és jóváhagyta.

Érdekeltségek: A szerzőnek nincsenek érdekeltségei.

\section{Irodalom}

[1] Act CLIV of 1997 on Health. [1997. évi CLIV. törvény az egészségügyről.] http://net.jogtar.hu/jr/gen/hjegy_doc.cgi?docid= 99700154.TV [Hungarian]

[2] Hungarian Medical Chamber. [Magyar Orvosi Kamara.] http:// www.mok.hu/info.aspx?sp=65 [Hungarian]

[3] Chamber of Hungarian Health Care Professionals. [Magyar Egészségügyi Szakdolgozói Kamara.] http://www.meszk.hu/ info.aspx?sp $=55$ [Hungarian]

[4] Act I of 2012 on the Labor Code. [2012. évi I. törvény a munka törvénykönyvéról.] http://net.jogtar.hu/jr/gen/hjegy_doc. cgi?docid=Al200001.TV [Hungarian]

[5] Act XXXIII of 1992 on the Legal Status of Civil Servants. [1992. évi XXXIII. törvény a közalkalmazottak jogállásáról.] http:// net.jogtar.hu/jr/gen/hjegy_doc.cgi?docid=99200033.TV [Hungarian]

[6] Act CXCIX of 2011 on Public Service Officials. [2011. évi CXCIX. törvény a közszolgálati tisztviselőkről.] http://net. jogtar.hu/jr/gen/hjegy_doc.cgi?docid=Al100199.TV [Hungarian]

[7] Act CLXV of 2013 on Complaints and Public Interest Disclosures. [2013. évi CLXV. törvény a panaszokról és a közérdekú bejelentésekről.] http://net.jogtar.hu/jr/gen/hjegy_doc. cgi?docid=A1300165.TV [Hungarian]

[8] Act V of 2013 on the Civil Code. [2013. évi V. törvény a polgári törvénykönyvről.] http://net.jogtar.hu/jr/gen/hjegy_doc. cgi?docid=A1300005. TV\&celpara=6:23\#xcelparam [Hungarian]

[9] Hungarian National Authority for Data Protection and Freedom of Information. [Nemzeti Adatvédelmi és Információszabadság Hatóság.] http://www.naih.hu/ [Hungarian]

[10] Equal Treatment Authority. [Egyenlő Bánásmód Hatóság.] http://www.egyenlobanasmod.hu/ [Hungarian]

[11] Act $\mathrm{C}$ of 2012 on the Criminal Code. [2012. évi C. törvény a büntető törvénykönyvről.] http://net.jogtar.hu/jr/gen/hjegy_ doc.cgi?docid=A1200100.TV [Hungarian]

[12] National Centre for Patients' Rights and Documentation. [Országos Betegjogi, Ellátottjogi, Gyermekjogi és Dokumentációs Központ.] http://www.obdk.hu/ [Hungarian]

[13] Act CXVI of 2000 on Mediation in Health Care. [2000. évi CXVI. törvény az egészségügyi közvetítői eljárásról.] http:// net.jogtar.hu/jr/gen/hjegy_doc.cgi?docid=A0000116.TV [Hungarian]

[14] Annual activity report of National Centre for Patients' Rights and Documentation of 2014. [OBDK, 2014. évi szakmai beszámoló.] http://www.obdk.hu/UserFiles/beszamolo_2014.pdf [Hungarian]

[15] Case Law/Esetjog: 2229 Civil Principal Decision of the Supreme Court of 2010. [A Legfelsőbb Bíróság 2229/2010. számú polgári elvi határozata (EBH2010. 2229.)] http://www.kuria-birosag.hu/hu/elvhat/22292010-szamu-polgari-elvi-hatarozat Pfv. III. 21.318/2008 Decision of the Supreme Court of 2010. [A Legfelsőbb Bíróság Pfv. III. 21.318/2008. számú polgári jogi döntése (BH2010. 65.)] http://www.petrassydr.hu/images/ stories/BH2010.65.pdf

1867 Civil Principal Decision of the Supreme Court of 2008. [A Legfelsőbb Bíróság 1867/2008. számú polgári elvi határozata (EBH2008. 1867.)] http://www.hqsoft.eu/k/images/stories / EBH2008.1867.pdf [Hungarian]

(Mina András dr., Budapest, Pf. 646, 1365 e-mail: mina.andras@obdk.hu) 